\title{
INKOMSTEBELASTINGHANTERING VAN KORTING ONTVANG IN DIE HANDE VAN 'N NIE- HANDELDRYWENDE PERSOON
}

\author{
Sophia Brink* \\ Universiteit Stellenbosch \\ sophiabrink@sun.ac.za
}

Received: April 2013

Accepted: August 2013

\begin{abstract}
For income tax purposes, a taxpayer operating a business will account for discount received differently from a taxpayer not operating a business. When a taxpayer operating a business obtains goods or services at a discount, the taxpayer can claim a section $11(\mathrm{a})$ deduction at the value of the goods or services, net of the discount received. The discount reduces the value of the net reduction of taxable income and the taxpayer is effectively taxed on the discount received. A taxpayer who is not operating a business will not qualify for a section 11 (a) deduction (read together with section 23(g)) for goods or services obtained (it does not meet the requirements 'for the purposes of trade' and 'in the production of income'). Discount received in the hands of a non-trading person (often a natural person) is currently not subject to normal South African income tax. The main objective of this article is to investigate whether the existing provisions in the Income Tax Act No. 58 of 1962 and related case law provide a basis for taxing discount received in the hands of the non-trading individual. In order to meet this objective, local literature was analysed to determine the correct income tax treatment and it was found that discount received by a non-trading person meets all the requirements of the 'gross income' definition and consequently should be taxable.
\end{abstract}

Keywords

Vereffeningskorting, afslag, bruto inkomste, Inkomstebelastingwet nr. 58 van 1962, kontantkorting, korting, korting ontvang

*Ms S Brink is a lecturer in the Department of Accounting, Stellenbosch University, South Africa. 


\section{INLEIDING}

Wanneer ' $n$ belastingpligtige wat ' $n$ bedryf beoefen goedere of dienste teen ' $n$ afslag of korting verkry, sal die belastingpligtige, ingevolge die Inkomstebelastingwet nr. 58 van 1962 ("die Wet"), ' $n$ artikel $11(a)$-aftrekking eis teen die waarde van die goedere of dienste na aftrekking van die afslag of korting ontvang, of die volle koopprys as aftrekking eis en die afslag op die inkomsterekening toon om belas te word. Vir handeldrywende persone wil dit voorkom asof die heersende praktyk in Suid-Afrika is dat afslag of korting ontvang nie belas word nie deurdat dit nie apart by bruto inkomste ingesluit word nie; eerder deurdat die afslag of korting die waarde van die aftrekking verminder dra dit egter by tot ' $n$ hoër belasbare inkomste en word dit in werklikheid belas. ' $n$ Belastingpligtige wat egter nie ' $n$ bedryf beoefen nie, sal nie slaag om ' $n$ artikel $11(\mathrm{a})$-aftrekking (saamgelees met artikel $23(\mathrm{~g})$ ) te eis vir goedere of dienste verkry nie: daar word nie voldoen aan die vereistes van die 'beoefening van ' $n$ bedryf' en 'in die voortbrenging van inkomste' nie. Die afslag of korting word nie deur die belastingpligtige by bruto inkomste ingesluit nie en word vervolgens nie belas nie. Afslag of korting ontvang word dus verskillend hanteer deur ' $n$ belastingpligtige wat ' $n$ bedryf beoefen en ' $n$ belastingpligtige wat nie ' $n$ bedryf beoefen nie. Die vraag ontstaan of afslag of korting ontvang in die hande van ' $n$ belastingpligtige wat nie ' $n$ bedryf beoefen nie, nie afsonderlik by bruto inkomste ingesluit moet word nie.

Die omvang van literatuur rakende die belasbaarheid van afslag of korting in Suid-Afrika is beperk. Bestaande literatuur rakende die inkomstebelastingimplikasie van afslag of korting fokus hoofsaaklik op die verskaffer wat afslag of korting toestaan. Daar kan in 'n verkoopsooreenkoms ooreengekom word dat die verbruiker, indien hy binne 'n bepaalde tydperk die betaling maak, onvoorwaardelik geregtig sal wees op 'n korting op die verkoopprys. Die vraag ontstaan of die totale verkoopprys as bruto inkomste aan die verskaffer toeval of, as alternatief, 'n kleiner bedrag wat vasgestel word deur'n beraming te maak van die korting wat in die geval van tydige betaling van die faktuur toegestaan sal word (Stiglingh, Koekemoer, Van Schalkwyk, Wilcocks \& De Swardt, 2012:24). Die regspraak oor of ' $n$ bedrag voor of na aftrekking van die korting by bruto inkomste ingesluit moet word, verskil. Die bewoording van elke verkoopsooreenkoms is uniek en sal die waarde van die bedrag ontvang met die verkooptransaksie bepaal.

Afslag of korting kan ook beskou word as voordele soortgelyk aan punte of myle verdien ingevolge ' $n$ kliëntelojaliteitsprogramtransaksie (Rowley, 2005:195). Brink en Viviers (2012:438) het bevind dat selfs al word kliëntelojaliteitsprogramvoordele ontvang nie tans in Suid-Afrika belas nie, bied die bestaande bepalings in die Wet en verwante regspraak wel ' $n$ basis vir die belasbaarheid van ' $n$ kliëntelojaliteitsprogramtransaksie in die hande van die verbruiker as ' $n$ natuurlike persoon.

Uit bogenoemde literatuur het dit duidelik geblyk dat daar steeds ' $n$ gaping voorkom in die ondersoek rakende die belasbaarheid van afslag of korting in die hande van ' $n$ verbruiker as niehandeldrywende natuurlike persoon. Die hoofdoel van die navorsing wat in hierdie artikel ter sprake is, was om aandag aan hierdie gaping te gee deur ondersoek in te stel of die bestaande bepalings in die Wet en verwante plaaslike regspraak ' $n$ basis bied, al dan nie, vir die belasbaarheid van afslag of korting in die hande van die Suid-Afrikaanse niehandeldrywende natuurlike persoon.

Ten einde hierdie hoofdoelwit te bereik, is dit eerstens nodig om ' $n$ beter begrip van die tipes afslag en korting beskikbaar in die Suid-Afrikaanse mark te verkry asook die werking van elk 
hiervan. As vertrekpunt vir die artikel word die tipes afslag of korting tesame met elk se omskrywing gevolglik bespreek. Met inagneming van die tipes afslag of korting, sowel as elkeen se omskrywing, word die inkomstebelastinghantering van afslag of korting in die hande van 'n niehandeldrywende natuurlike persoon vervolgens ontleed deur na relevante belastingwetsartikels, akademiese werke asook regspraak te verwys. Ten einde ' $n$ afslag- of kortingtransaksie in sy geheel te beoordeel, word die inkomstebelastinggevolge vir die niehandeldrywende natuurlike persoon wat die afslag of korting ontvang, vergelyk met die verskaffer wat die afslag of korting toestaan.

\section{TIPES AFSLAG OF KORTING EN OMSKRYWINGS}

Afslag of korting kan tipies onderverdeel word in:

- ' $n$ afslag of korting wat onvoorwaardelik op die leweringsdatum toegestaan word (byvoorbeeld handelskorting) en

- ' $n$ afslag of korting wat voorwaardelik op die plaasvind van ' $n$ gebeurtenis wat na die lewering volg, toegestaan word (byvoorbeeld vereffeningskorting of kontantkorting) (Beneke, 2010: par 4.3).

Handelskorting is ' $n$ bedrag of ' $n$ koers waarteen die katalogus-, lys-, of kleinhandelsprys van ' $n$ item verminder word wanneer dit aan ' $n$ groothandelaar (Business Dictionary, 2011) eerder as aan die eindverbruiker verkoop word (Accounting Tools, 2011). Handelskorting weerspieël die groothandelaar se winsmarge en wissel gewoonlik direk eweredig met die hoeveelheid van die spesifieke item wat aangekoop word (Business Dictionary, 2011).

Vereffeningskorting is ' $n$ aansporing wat ' $n$ verskaffer aan ' $n$ verbruiker bied vir die vereffening van ' $n$ bedrag verskuldig voor die ooreengekome vereffeningsdatum. Die verskaffer sal gewoonlik die bedrag verskuldig deur die verbruiker met ' $n$ persentasie of ' $n$ vasgestelde bedrag verminder. Byvoorbeeld: ' $n$ verskaffer bied ' $n$ twee persent vereffeningskorting op ' $n$ faktuur wat binne 30 dae betaalbaar is indien die verbruiker binne die eerste 10 dae vanaf ontvangs van die faktuur reeds die skuld vereffen. Vereffeningskorting toegestaan is nuttig vir die verskaffer, aangesien dit hom in staat stel om vinniger toegang tot die kontant te kry ten einde dit in die besigheid van die verskaffer terug te ploeg (Investopedia, 2011).

\section{OMVANG VAN DIE STUDIE}

Ten einde die omvang van die studie te beperk, en ook aangesien handelskorting normaalweg (of in die meeste gevalle) aan ' $n$ belastingpligtige wat ' $n$ bedryf beoefen, toegestaan word, word handelskorting ontvang van die omvang van hierdie artikel uitgesluit.

Die bepalings en voorwaardes waaronder vereffeningskorting beding kan word, verskil. Daar is gevolglik besluit om slegs op die volgende spesifieke tipe vereffeningskorting ontvang te fokus: 'n (potensiële) vereffeningskorting wat beding word tydens die oorspronklike aankoop- of dienslewerringstransaksie. Transaksies waartydens later toevallige kortings toegestaan word wat nie tydens die oorspronklike transaksie beding is nie, is gevolglik van die omvang van die studie uitgesluit. ' $n$ Voorbeeld van ' $n$ vereffeningskorting wat beding word tydens die oorspronklike aankoop- of diensleweringstransaksie is soos volg: 'n Mediese praktyk bepaal dat $10 \%$-vereffeningskorting toegestaan word indien 'n pasiënt die volle bedrag, soos gefaktureer 
op die datum van die doktersbesoek, binne 30 dae na die besoek (diensleweringstransaksie) betaal. Hierdie bepalings en voorwaardes word met die oorspronklike transaksie reeds aan die verbruiker gekommunikeer en oor ooreengekom. Dit is belangrik om daarop te let dat die bedoeling in hierdie geval nie is om die oorspronklik ooreengekome prys te wysig nie, maar eerder om 'iets' aan die verbruiker terug te gee as beloning of aansporing vir vroeë vereffening van 'n skuld. Die artikel stel slegs ondersoek in na die inkomstebelastinghantering van vereffeningskorting ontvang in die hande van ' $n$ niehandeldrywende inwoner van Suid-Afrika. ' $n$ Nie-inwoner wat vereffeningskorting in Suid-Afrika ontvang word gevolglik van die omvang van die studie uitgesluit, alhoewel dit nie beteken dat die posisie vir nie-inwoners noodwendig anders sal wees as dié van Suid-Afrikaanse belastingbetalers nie.

\section{ONTLEDING VAN DIE SUID-AFRIKAANSE INKOMSTEBELASTING- WETGEWING}

Met inagneming van die tipes afslag of korting sowel as elkeen se omskrywing word die inkomstebelastinghantering van vereffeningskorting in die hande van 'n natuurlike persoon (wat die vereffeningskorting ontvang) ontleed deur na relevante artikels van die Inkomstebelastingwet, asook regspraak, te verwys. Daar sal telkens na die niehandeldrywende natuurlike persoon wat die vereffeningskorting ontvang, verwys word as die belastingpligtige.

\subsection{Algemene bruto inkomste: definisie}

Die basis vir die heffing van normale belasting berus in die definisie van 'bruto inkomste' in artikel I van die Wet. Die omskrywing van 'bruto inkomste' in die Wet lees soos volg:

Bruto inkomste met betrekking tot ' $n$ jaar van aanslag -

- in die geval van enige inwoner, die totale bedrag hetsy in kontant of andersins, ontvang deur of toegeval aan of ten gunste van so ' $n$ inwoner ...

gedurende die bedoelde jaar of tydperk van aanslag, met uitsluiting van ontvangstes of toevallings van ' $n$ kapitale aard.

Normale belasting kan alleenlik gehef word indien daar aan al die vereistes van die definisie voldoen word. Onderstaande drie komponente van die omskrywing $(4.1 .1-4.1 .3)$ is van kardinale belang ten einde te bepaal of vereffeningskorting ontvang by die belastingpligtige se bruto inkomste ingesluit moet word (te wete dat 'n bedrag moet bestaan, dit moet deur die belastingbetaler ontvang word of aan hom/haar toegeval het, en hierdie bedrag is nie van 'n kapitale aard nie). Al die komponente van die definisie is oorweeg en slegs dié wat relevant is vir die navorsing word individueel oorweeg en bespreek. Daar word telkens oorweeg of daar aan die vereiste voldoen word en, indien wel, ook op watter tydstip daar aan die vereiste voldoen word. Die twee tydstippe wat ingevolge ' $n$ vereffeningskortingtransaksie van toepassing is, is die transaksiedatum ingevolge waarvan die oorspronklike koop- of dienslewerings kontrak gesluit word, met ander woorde ook wanneer oor die potensiële basis vir die vereffeningskorting ooreengekom word, en die vereffeningsdatum (die voorafbepaalde tydslimiet) wanneer die vereffeningskorting ontvang word. 


\subsubsection{Ontvang deur of toegeval aan}

Die hof het in CIR v Delfos [1933] 6 SATC 92 bepaal dat ' $n$ bedrag óf ontvang moet wees deur óf toegeval moet wees aan die belastingpligtige gedurende die jaar van aanslag alvorens ' $n$ bedrag by bruto inkomste ingesluit kan word. Dit word hieronder aangevoer dat die belastingpligtige beide ' $n$ ontvangs en 'n toevalling het waar dit op die persoonlike reg uit 'n vereffeningskortingstransaksie geregtig word. (Vanuit 'n taalkundige perspektief is dit egter waarskynlik meer korrek om daarna te verwys dat 'n reg toeval, eerder as wat dit ontvang word. Beide posisies word nietemin bespreek.)

\section{Betekenis van 'ontvang deur'}

In Geldenhuys v CIR [1947] 14 SATC 419 is beslis dat die woorde 'ontvang deur' beteken dat die belastingpligtige iets namens homself en tot sy eie voordeel moet ontvang. ' $n$ Belastingpligtige kan dus nie belasting betaal op bedrae wat deur hom ontvang is tot die voordeel van ' $n$ ander persoon nie.

In die toepassing van bogenoemde op vereffeningskorting ontvang, kan soos volg geredeneer word: Wanneer ' $n$ belastingpligtige binne die voorafbepaalde tydperk uitstaande skuld vereffen, op grond van ' $n$ aankoop- of dienslewerringstransaksie ingevolge waarvan vereffeningskorting toegestaan is, betaal die belastingpligtige ' $n$ bedrag na aftrekking van vereffeningskorting. Die belastingpligtige ontvang dus ' $n$ voordeel namens homself en tot sy eie voordeel. Daar word dus op die datum van vereffening aan die vereiste van bruto inkomste 'ontvang deur' voldoen.

Die vraag ontstaan of die belastingpligtige wel ' $n$ voordeel ontvang indien hy versuim om die uitstaande skuld voor die verstryking van die vereffeningsdatum te vereffen. In so ' $n$ geval word die vereffeningskorting verbeur en die belastingpligtige ontvang in werklikheid geen voordeel nie. In hierdie geval sal die belastingpligtige nie aan die vereiste of gedeelte van die omskrywing van bruto inkomste 'ontvang deur' voldoen nie. Selfs al is die voordeel nie self deur die belastingpligtige (tot sy eie voordeel) ontvang nie (met ander woorde daar word nie aan die vereiste 'ontvang deur' voldoen nie), kan normale belasting steeds gehef word indien dit aan die belastingpligtige toegeval het (teenoor 'ontvang deur').

\section{Betekenis van 'toegeval aan'}

In Lategan WH v CIR [1926] 2 SATC 16 is beslis dat die betekenis van die woorde 'toegeval aan' in werklikheid 'geregtig op' beteken. Die beginsel wat in die konteks van vereffeningskorting uit hierdie saak afgelei kan word, is dat die reg tot korting deel van bruto inkomste uitmaak in die jaar waarin die belastingpligtige geregtig word op die reg, ten spyte daarvan dat die reg moontlik eers in ' $n$ daaropvolgende belastingjaar opeisbaar is (Stiglingh et al., 2012:23). Vir doeleindes van die begrip 'toegeval aan' is die fisiese eis of benutting van die vereffeningskorting (met ander woorde of dit ooit opgeëis word) gevolglik irrelevant (Stiglingh et al., 2012:23). Dit moet onderskei word van die bevinding in Mooi v SIR [1972] 34 SATC 1. In hierdie saak is bevind dat die voordee/ ontvang uit aandeleopsies eers plaasvind by die uitoefening van die reg tot die opsies, en nie wanneer die belastingpligtige die reg om die opsies uit te oefen, ontvang nie. Vir doeleindes van toevalling is die ontvangs van ' $n$ voordeel gevolglik irrelevant. Dit sluit aan by Ochberg $v$ CIR [1933] 6 SATC 1 waar beslis is dat die waarde van ' $n$ nie-monetêre bedrag van inkomste objektief bepaal moet word en dat die waarde daarvan vir ' $n$ spesifieke belastingpligtige irrelevant is (Williams, 1995:113). Die hof het in hierdie saak bevind dat die vraag of die belastingpligtige ' $n$ voordeel verkry het, nie relevant is nie (Jordaan, Kolitz, Stein \& Stiglingh, 2005:16). 
Die beginsel dat die begrip 'toegeval aan' beteken 'geregtig op' is in Ochberg $v$ CIR [1933] 6 SATCl en Mooi $v$ SIR [1972] 34 SATC 1 bevestig. In die twee sake word die woord 'onvoorwaardelik' tot die betekenis van 'toegeval aan' bygevoeg. In CIRv People's Stores (Walvis Bay) (Pty) Ltd [1990] 52 SATC 9 is bepaal dat 'onvoorwaardelik geregtig' genoeg is vir toevalling ofskoon dit nog nie afdwingbaar is nie. Daar is beslis dat die belastingpligtige onvoorwaardelik geregtig op ' $n$ bedrag moet wees. Indien die reg om toekomstige betalings te kan eis voorwaardelik is, vind geen toevalling plaas nie. Toevalling kan alleenlik plaasvind nadat alle voorwaardes vervul is, omdat die belastingpligtige, totdat dit gebeur, nie op die bedrag geregtig is nie. Vir doeleindes van die begrip 'toevalling' is die subjektiewe bedoeling van die belastingpligtige gevolglik irrelevant. Die beginpunt van die ondersoek moet altyd die onderliggende verbintenisreg (geregtigheid) van die transaksie wees (Stiglingh et al., 2012:23).

Ingevolge vereffeningskorting moet bepaal word wanneer die reg die belastingpligtige toegeval het. Die transaksiedatum en die vereffeningsdatum moet van mekaar onderskei en dienooreenkomstig oorweeg word. Indien daar bevind word dat toevalling op die transaksiedatum plaasvind, kan die belastingpligtige moontlik op ' $n$ bedrag belas word selfs al word die vereffeningskorting nooit benut nie. Soos reeds genoem is, is die ontvangs van ' $n$ voordeel nie ' $n$ voorvereiste vir toevalling om plaas te vind nie.

\section{Onvoorwaardelik geregtig op}

$0 p$ die transaksiedatum ingevolge waarvan vereffeningskorting ooreengekom word, ontvang die belastingpligtige alleenlik ' $n$ spes (moontlikheid) op korting. Die reg tot korting ontstaan eers wanneer die belastingpligtige binne die voorafbepaalde tydperk sy skuld vereffen.

Ingevolge vereffeningskorting word slegs een voorwaarde gestel vir die benutting van vereffeningskorting, naamlik dat die vereffening voor of op die vereffeningsdatum moet geskied. Die belastingpligtige sal onvoorwaardelik geregtig wees om korting te ontvang op die vereffeningsdatum. Daar word dus op die datum van vereffening aan die vereiste van bruto inkomste 'toegeval aan' voldoen.

\section{Tydstip van ins/uiting by bruto inkomste}

In SIR v Silverglen Investments (Pty) Ltd [1969] 30 SATC 199 is beslis dat die insluiting by bruto inkomste altyd op die vroegste van ontvangste of toevalling geskied. In die geval van vereffeningskorting sal die belastingpligtige gelyktydig aan die vereiste van die bruto inkomste se definisie van 'ontvang deur' en 'toegeval aan' voldoen. Gevolglik sal ' $n$ insluiting by bruto inkomste op die datum van vereffening plaasvind.

Indien ' $n$ totale bedrag, hetsy in kontant of andersins, wat nie van 'n kapitale aard is nie deur ' $n$ belastingpligtige ontvang word of aan hom toeval, word daar aan die omskrywing van 'bruto inkomste' in die Wet voldoen. (Verwys ook na die verdere breedvoerige bespreking van CSARS v Brummeria Renaissance (Pty) Ltd and others [2007] 69 SATC 205 hieronder ter verdere ondersteuning van hierdie argument.) Ten einde die bedrag by bruto inkomste in te sluit, moet die waarde van die bedrag bepaal word.

\section{Waardering van ontvangste en toevallings}

CIR v Delfos [1933] 6 SATC 92, Lategan WH v CIR [1926] 2 SATC 16 en CIR v People's Stores (Walvis Bay) (Pty) Ltd [1990] 52 SATC 9 stel 'n definitiewe voorvereiste vir die insluiting van 'n bedrag by bruto inkomste, naamlik dat dit ' $n$ bepaalbare randwaarde moet hê. In CIR v Butcher Bros (Pty) Ltd [1945] 13 SATC 21 is hierdie beginsel ook bevestig. ' $n$ Insluiting by bruto inkomste is onmoontlik indien ' $n$ ontvangste of ' $n$ toevalling geen bepaalbare randwaarde het nie. Daarom 
moet ' $n$ ontvangste of toevalling, in ' $n$ ander vorm as kontant, waardeerbaar wees. Die algemene beginsel is dat indien die belastingpligtige ' $n$ ander vorm van eiendom (naamlik anders as in kontant) ontvang, dit die monetêre waarde (Williams, 1995:107) of die markwaarde (Stiglingh et al., 2012:18) van sodanige bate is wat by die belastingpligtige se bruto inkomste ingesluit moet word. In Ochberg v CIR [1933] 6 SATC 1 en Lace Proprietary Mines Ltd v CIR [1938] 9 SATC 349 is bepaal dat die waarde van ' $n$ nie-monetêre bedrag ' $n$ feitevraag is en objektief bepaal moet word (Williams, 1995:110). Die vraag ontstaan op watter tydstip die waarde van die ander vorm van eiendom ontvang bepaal moet word. Die kwessie is in Lace Proprietary Mines Ltd $v$ CIR [1938] 9 SATC 349 behandel waar beslis is dat die waarde van die eiendom die prys wat op die datum van ontvangs of toevalling bekom kan word, sal verteenwoordig (Williams 1995:112). Ingevolge artikel 102 van die Belastingadministrasiewet nr. 28 van 2011 (van krag vanaf 1 Oktober 2012) rus die bewyslas dat ' $n$ waarde wat aan ' $n$ 'bedrag' gekoppel word korrek is op die belastingpligtige. Hierdie artikel vervang wesenlik artikel 82 van die Wet en oorheers die beginsel wat in CIR v Butcher Bros (Pty) Ltd 194513 SATC 21 neergelê is, dat die onus om ' $n$ bedrag vas te stel op die Kommissaris rus.

\section{Waardering van die reg tot korting ontvang}

Vir die spesifieke tipe vereffeningskortingsooreenkoms wat ondersoek word (verwys na punt 3, Omvang van die studie) geld die volgende: Tydens ' $n$ aankoop- of dienslewerringstransaksie sal die vereffeningskorting ooreengekom word (dit kan ' $n$ persentasie van die koopsom of ' $n$ vasgestelde bedrag verteenwoordig). Die reg tot korting wat met vereffening op die vereffeningsdatum ontstaan, is gevolglik bepaalbaar deur na die vereffeningskorting waaroor oorspronklik ooreengekom is, te verwys.

\subsubsection{Totale bedrag hetsy in kontant of andersins}

Waar ' $n$ vereffeningskorting ter sprake is, is die voorwaarde dat sodra betaling binne ' $n$ voorafbepaalde tydperk plaasvind, die koper sy reg tot korting ontvang. Totdat die koper egter nie presteer deur betaling binne die voorgeskrewe tydperk nie, is hierdie voorwaarde nie vervul nie, en het die koper niks meer as ' $n$ spes nie. Op die transaksiedatum ingevolge waarvan vereffeningskorting ooreengekom word, ontvang die belastingpligtige gevolglik alleenlik' $n$ spes tot ' $n$ korting. ' $n$ Reg tot korting word eers met vereffening deur die belastingpligtige ontvang by vroeë betaling van die handelskuld (wat voor of op die vereffeningsdatum plaasvind, maar beslis nadat die oorspronklike transaksie wat tot die handelskuld gevolg gegee het, afgehandel is). Hierdie reg wat ontvang is, impliseer dat die belastingpligtige met vroegtydige vereffening minder kan betaal vir goedere of dienste wat reeds ontvang is. ' $n$ Ander manier om die benutting van vereffeningskorting te beskou, is soos volg: Die belastingpligtige betaal die volle aankoopprys (voor aftrekking van vereffeningskorting) op die vereffeningsdatum en die verskaffer vergoed die belastingpligtige vir vroegtydige vereffening deur die vereffeningskorting-gedeelte aan die belastingpligtige terug te betaal. In werklikheid kry die belastingpligtige geld terug op ' $n$ vorige aankoop- of dienslewerringstransaksie. Die belastingpligtige verkry gevolglik 'n persoonlike reg ('n vorderingsreg) teenoor die verskaffer.

\section{'n Reg tot korting ontvang}

In CIR v People's Stores (Walvis Bay) (Pty) Ltd [1990] 52 SATC 9 is beslis dat selfs sonder die woorde 'hetsy in kontant of andersins', die omskrywing van 'bruto inkomste' by wyse van die begrip 'bedrag', nie alleenlik geld insluit nie, maar ook die waarde van elke vorm van eiendom, liggaamlik of onliggaamlik, wat deur die belastingpligtige verdien is, wat ' $n$ randwaarde het. 
Wanneer ' $n$ belastingpligtige binne die voorafbepaalde tydperk sy skuld vereffen, word ' $n$ reg tot korting verkry. Daar sal oor die waarde van die vereffeningskorting tydens die aankoop- of dienslewerringstransaksie ooreengekom word en gevolglik kan ' $n$ spesifieke randwaarde daaraan gekoppel word. Die belastingpligtige ontvang dus op die vereffeningsdatum ' $n$ reg op korting met ' $n$ spesifieke randwaarde. Dit beteken dat selfs al word kontant nie ontvang nie, word ' $n$ vorm van eiendom met ' $n$ bepaalbare randwaarde ontvang. Die waarde van die reg (vorm van eiendom) ontvang sal die randwaarde van die vereffeningskorting soos ooreengekom is, bedra. Daar word gevolglik aan die vereiste van bruto inkomste 'totale bedrag hetsy in kontant of andersins' voldoen.

Normale belasting kan alleenlik gehef word indien daar aan al die vereistes van die definisie voldoen word. Die laaste vereiste van die bruto inkomste-definisie 'met uitsluiting van ontvangstes of toevallings van 'n kapitale aard' word vervolgens bespreek.

\subsubsection{Met uitsluiting van ontvangstes of toevallings van 'n kapitale aard}

Die begrip 'kapitale aard' word nie in die Wet omskryf nie. Vanuit talle uiteenlopende hofuitsprake oor die onderwerp is dit duidelik dat daar nie ' $n$ onfeilbare toets bestaan vir die onderskeid tussen 'kapitaal' en 'inkomste' nie (Stiglingh et al., 2012:31). In CIR v Visser [1937] 8 SATC 271 is bepaal dat 'inkomste' deur 'kapitaal' gelewer word of dat dit iets in die aard van rente of 'vrugte' is wat deur die kapitale bedrag of 'boom' gelewer word. Hierdie beginsel is 'n waardevolle hulpmiddel vir inkomstebelasting, maar die toepassing daarvan is dikwels baie moeilik, omdat dit wat deur een persoon as ' $n$ kapitale bedrag of ' $n$ 'boom' beskou word, vir ' $n$ ander persoon rente of 'vrugte' kan beteken. Inkomste kan gevolglik beskou word as die 'vrug' van kapitaal, wat op die beurt as die 'boom' beskou kan word.

Daar moet bewys word dat die ontvangste of toevalling nie van ' $n$ kapitale aard is nie ten einde aan die definisie van bruto inkomste te voldoen. Die reg tot korting word op die vereffeningsdatum ontvang en hierdie reg tot korting word vir doeleindes van die vereiste 'met uitsluiting van ontvangstes of toevallings van ' $n$ kapitale aard' vervat in die definisie van bruto inkomste bespreek.

\section{'n Reg tot korting ontvang}

Die beslissing of ' $n$ bedrag kapitaal of inkomste is, ontstaan gewoonlik wanneer ' $n$ reg opgegee of oorgedra word (Huxham \& Haupt 2012:47). Die reg op korting word verkry op die vereffeningsdatum, en daar word tegelykertyd afstand gedoen van hierdie reg wanneer ' $n$ bedrag na aftrekking van vereffeningskorting betaal word ter vereffening van die belastingpligtige se skuld. Of ' $n$ bedrag wel kapitaal van aard is, is ' $n$ vraag wat beantwoord moet word met verwysing na die verskeie faktore, beide objektief en subjektief wat mag bestaan, wat in ag geneem moet word ten einde die aard daarvan te bepaal. Faktore wat oorweeg moet word, word hieronder bespreek.

\section{Bedoeling}

Die bedoeling van die belastingpligtige is die belangrikste toets wat deur howe gebruik word om te bepaal of die verkryging van 'n bedrag (soos hierbo bespreek) kapitaal of inkomste van aard is (Stiglingh et al., 2012:33). Die enigste rede waarom ' $n$ natuurlike persoon sal besluit om skuld, ingevolge waarvan vereffeningskorting oorspronklik ooreengekom is, binne die voorafbepaalde tydperk te betaal, is met die bedoeling om die vereffeningskorting te benut. Die bedoeling waarmee die reg verkry word, blyk duidelik daaruit deurdat daardie reg wat verkry is oombliklik 
verruil word vir ekonomiese voordeel, te wete die terugbetaling deur die verskaffer, prakties ten toon gestel deur die netto effek van betaling van die mindere skuldbedrag.

\section{Vaste kapitaal en bedryfskapitaal}

Howe het al in die verlede die onderskeid tussen vaste en bedryfskapitaal aangewend om tussen inkomste en kapitaal te onderskei. Vaste kapitaal omvat ' $n$ element van permanentheid, in die sin dat daar ' $n$ bedoeling is om die betrokke bate of reg op ' $n$ permanente basis aan te wend met die doel om inkomste daaruit te genereer (SB/ v Aveling [1978] 40 SATC 1). Hierdie beginsel is weer in Bloch $v$ SIR [1980] 42 SATC 7 bevestig. Dit is nie moontlik om ' $n$ reg tot korting ontvang op ' $n$ permanente basis aan te wend ten einde kapitale groei te bewerkstellig of om ' $n$ inkomsteproduserende struktuur (blywende voordeel) daar te stel nie. Die reg tot korting word op die vereffeningsdatum ontvang en tegelykertyd opgegee of oorgedra om uiteindelik ' $n$ bedrag na aftrekking van vereffeningskorting te betaal. Sodra die reg tot korting ontstaan, word dit aangewend; dit verval en bly nie voortbestaan as ' $n$ 'boom' wat 'vrugte'dra nie (toepassing van beginsel neergelê in CIR v Visser [1937] 8 SATC 271). Gevolglik blyk dit dat die reg tot korting ontvang as bedryfskapitaal kwalifiseer en as inkomste van aard geklassifiseer moet word.

\section{Kontinuïteit of frekwensie van transaksies}

Die frekwensie van ' $n$ spesifieke soort transaksie kan as aanduider gebruik word om vas te stel of die opbrengs wat daaruit voortvloei as kapitaal of as inkomste van aard geklassifiseer moet word (Stiglingh, 2012:38). 'n Hoë frekwensie van transaksies dui gewoonlik daarop dat die opbrengs inkomste van aard is, terwyl ' $n$ geïsoleerde of eenmalige transaksie op ' $n$ kapitale aard dui (alhoewel dit al meermale bevestig is dat hierdie oorweging nie uitsluitlik op 'n kapitale of inkomste -bedoeling kan dui nie). Vanuit ITC 1118 [1968] 30 SATC 133, ITC 677 [1949] 16 SATC 245 en ITC 692 [1950] 16 SATC 509 blyk dit duidelik dat die hof wel vantevore bloot die aantal transaksies as beslissende faktor aangewend het ten einde die belastingpligtige se bedoeling en gevolglik die aard van die ontvangste of toevalling vas te stel. Ingevolge vereffeningskorting sal die belastingpligtige op ' $n$ gereelde basis by verskillende verskaffers vir vereffeningskorting kan kwalifiseer en dit benut. ' $n$ Hoë frekwensie van transaksies sal gevolglik voorkom wat daarop dui dat die opbrengs wat daaruit voortvloei (in die vorm van kontant terugontvang) as inkomste van aard geklassifiseer moet word.

\section{Die tydperk wat die bate of reg gehou word}

Die tydperk wat ' $n$ reg gehou word, is op sigself nie deurslaggewend in die bepaling van die aard van die toevalling wat voortvloei uit die beskikking van daardie reg nie, maar dit is steeds ' $n$ faktor wat in ag geneem kan word (Clegg \& Stretch, 2012: par 5.3.4). Die tydperk wat die reg gehou word, ondersteun gewoonlik die bedoeling van die belastingpligtige en kan bykomende bewys lewer of ' $n$ reg kapitaal of inkomste van aard is. Die reg op korting word verkry op die vereffeningsdatum; hierdie reg word tegelykertyd opgegee wanneer ' $n$ bedrag na aftrekking van vereffeningskorting betaal word ter vereffening van die belastingpligtige se skuld. Die reg verval dus dadelik en word nie vir 'n tydperk gehou nie.

\section{Skenking ontvang}

' $n$ Bate wat ontvang word by wyse van ' $n$ geskenk of skenking is kapitaal van aard (Stiglingh et al., 2012:42). ' $n$ Skenking word in artikel 55 van die Wet omskryf as ' $n$ gratis oormaking van eiendom, en ook ' $n$ gratis afstanddoening van ' $n$ reg. Vereffeningskorting kan egter nie as ' $n$ geskenk (wat gratis ontvang word) beskou word nie, aangesien die belastingpligtige (verbruiker) self moet presteer, naamlik die skuld voor die ooreengekome tydperk moet aflos om dit te 
verdien. ' $n$ Skenking kom nie voor ingevolge ' $n$ vereffeningskortingtransaksie nie, aangesien ' $n$ quid pro quo teenwoordig is (toepassing van die beginsel neergelê in Welch's Estate $v$ Commissioner for SARS [2005] (4) SA 173 (HHA)).

\section{Gevolgtrekking}

Die reg tot korting, oftewel die vereffeningskorting ontvang, is inkomste van aard en daar word gevolglik aan die vereiste van bruto inkomste 'met uitsluiting van ontvangstes of toevallings van ' $n$ kapitale aard' voldoen.

Ter samevatting: Wanneer die belastingpligtige binne die vooraf ooreengekome tydperk sy skuld vereffen en vereffeningskorting ontvang, word daar aan al die vereistes van die algemene definisie van bruto inkomste van die Wet voldoen en moet die waarde van die vereffeningskorting by die belastingpligtige se bruto inkomste ingesluit word.

Ten einde alle moontlike aspekte van ' $n$ vereffeningskortingstransaksie vir inkomstebelastingdoeleindes te oorweeg, word vereis dat dit vergelyk word met die hantering van inkomstebelasting vir die verskaffer wat die vereffeningskorting toestaan.

\subsection{Inkomstebelastinghantering van afslag of korting deur die verskaffer}

Die volgende handel oor afslag of korting wat voorwaardelik toegestaan word by ' $n$ gebeurtenis wat ná die lewering plaasvind: Daar kan in ' $n$ verkoopsooreenkoms bepaal word dat die verbruiker voorwaardelik op korting (byvoorbeeld vereffeningskorting) geregtig is op grond van ' $n$ toekomstige gebeurtenis (byvoorbeeld indien die verbruiker binne ' $n$ bepaalde tydperk die faktuur vereffen). Die vraag ontstaan of die totale verkoopprys of ' $n$ kleiner bedrag as bruto inkomste aan die verskaffer (belastingpligtige) toeval. Die kleiner bedrag waarna verwys word, is die verkoopprys minus die beraamde korting in die geval van die plaasvind van die toekomstige gebeurtenis (tydige betaling van die faktuur). Die regspraak oor of ' $n$ bedrag voor of na aftrekking van korting met die verkooptransaksie by bruto inkomste ingesluit moet word, verskil (Stiglingh et al., 2012:24). In wese berus die verskil daarop of 'n nuwe transaksie plaasvind by vereffening ingevolge waarvan die belastingpligtige ' $n$ reg tot korting ontvang, en of die oorspronklike verkoopprys bloot gewysig word. Vir laasgenoemde is daar geen nuwe regte en verpligtinge wat geskep word nie. By eersgenoemde egter word nuwe regte en verpligtinge geskep, wat natuurlik potensiële inkomstebelastingimplikasies kan hê.

In ITC 1815 [2006] 68 SATC 312 het die belastingpligtige die netto verkoopprys ná aftrekking van die vereffeningskorting soos per standaardverkoopsooreenkoms in die berekening van sy bruto inkomste in ag geneem. Die kwessie in die saak was of die vereffeningskorting deel van die belastingpligtige se bruto inkomste uitmaak al dan nie. Die belastingpligtige het aangevoer dat toevalling afhanklik is van die verkoopsooreenkoms en dat hy nie geregtig is om die kortingsbedrag te verhaal tot en met die verstryking van die gegewe kortingsperiode nie. Levinsohn ARP dui aan dat die betekenis van 'betaling' die betaling van die gefaktureerde bedrag en dit wat op die rekeningstaat sal verskyn verteenwoordig. Hy noem verder dat die ooreenkoms daarvoor voorsiening maak dat indien betaling teen ' $n$ sekere datum geskied die verbruiker op die aftrekking van 'n korting geregtig sal wees. Die belastingpligtige sal die volle verkoopprys debiteer. Alleenlik met tydige vereffening sal die korting toegestaan word, wat aandui dat die verskaffer se bedoeling is om die volle leweringsbedrag te ontvang op die datum van die faktuur en rekeningstaat wat die gefaktureerde verkoopprys weerspieël. Gevolglik het 
toevalling van die volle gefaktureerde bedrag op die rekeningstaatdatum plaasgevind en het die hof beslis dat die belastingpligtige die bruto bedrag (sonder die verrekening van enige afslag of korting) by bruto inkomste moet insluit (Stretch \& Silke, 2010). In ITC 1645 [1995] 61 SATC 31 het die hof dieselfde standpunt ingeneem en bepaal dat die totale gefaktureerde verkoopprys aan die verkoper toeval. Die belastingpligtige kon gevolglik nie die moontlike korting wat dalk in die toekoms toegestaan sal word op die datum van verkoop van bruto inkomste uitsluit nie (Stiglingh et al., 2012:25).

In GUD Holdings Ltd $v$ CSARS [2007] 69 SATC 115 het die hof ' $n$ ander benadering gevolg as in ITC 1815 [2006] 68 SATC 312 en ITC 1645 [1995] 61 SATC 31. In hierdie saak het die belastingpligtige kontraktueel met verbruikers ooreengekom dat hulle geregtig sal wees op ' $n$ vereffeningskorting indien betaling voor of op die 25 ste dag van die maand wat volg op die maand waarin die faktuur uitgereik is, sou geskied. Op die jaareinde (ook die einde van die belastingjaar) was daar sekere gelde uitstaande ten opsigte waarvan die vereffeningskorting nog kon geld. Die vraag het ontstaan of die verbruikers vir die volle bedrag of die verdiskonteerde bedrag aanspreeklik sou wees. Die hof het in die guns van die belastingpligtige bevind en dat hy met die sluiting van die kontrak slegs onvoorwaardelik op die verdiskonteerde verkoopprys geregtig was, en het beslis dat slegs daardie gedeelte van die uitstaande bedrae by die belastingpligtige se bruto inkomste ingesluit moet word (met ander woorde, die verhoogde gedeelte van die prys sou eers belas word indien die belastingpligtige onvoorwaardelik ook hierop geregtig sou word). Die vereffeningskortingperiode moet dus eers verloop voordat die belastingpligtige op die volle verkoopprys geregtig sal wees. Hurt J voer aan dat dit die bedoeling van die belastingpligtige en die verbruiker is dat die verbruiker goedere aankoop teen die netto prys ná vereffeningskorting soos gestipuleer in die standaardverkoopvoorwaardes. Die voorskrif dat die geld voor ' $n$ sekere datum betaalbaar is, is ' $n$ aansporing vir die verbruiker om die laer prys te benut. Die verbruiker sal dus net aanspreeklik gehou word vir die volle faktuurbedrag indien vereffening nie betyds plaasvind nie. Op grond hiervan is die vereffeningskorting, soos aangedui in die standaardverkoopsooreenkoms, eerder ' $n$ boete of straf vir laat betaling as ' $n$ korting in GUD Holdings $L t d$ se saak. As die verbruiker gevolglik versuim om binne die ooreengekome tydperk te betaal, sal die vereffeningskorting in daardie stadium eers as bruto inkomste van die belastingpligtige erken word. Die hof was van mening dat op grond van Lategan WH v CIR [1926] 2 SATC 16 en CIR v People's Stores (Walvis Bay) (Pty) Ltd [1990] 52 SATC 9, die vraag ontstaan: 'Wat was die reg van die belastingpligtige op jaareinde?' Gebaseer op die benadering van Watermeyer J in Lategan WH v CIR [1926] 2 SATC 16 sou dit verkeerd wees om die totale faktuurbedrag by die belastingpligtige se bruto inkomste in berekening te bring (Stretch \& Silke, 2010).

Dit is jammer dat die hof in GUD Holdings Ltd v CSARS [2007] 69 SATC 115 nie die uitwerking van die voorbehoudsbepaling tot die 'bruto inkomste'-definisie wat ingevoeg is ná die beslissing in CIR v People's Stores (Walvis Bay) (Pty) Ltd [1990] 52 SATC 9 oorweeg het nie. Die voorbehoudsbepaling tot die 'bruto inkomste'-definisie lees soos volg:

Met dien verstande dat waar 'n belastingpligtige gedurende 'n jaar van aanslag op ' $n$ bedrag geregtig geword het wat betaalbaar is op 'n datum of datums wat na die laaste dag van bedoelde jaar val, daar geag word gedurende bedoelde jaar aan hom toe te geval het -

(a) indien die belastingpligtige voor of op 23 Mei 1990 'n opgawe van inkomste verstrek het ... of

(b) in enige ander geval, bedoelde bedrag. 
Is dit nie moontlik dat die effek van paragraaf (b) van die eerste voorbehoudsbepaling vereis dat die belastingpligtige die bruto bedrag van die skuld ontvangbaar vir die verkoop van goedere by bruto inkomste insluit in die jaar waartydens die goedere verkoop is nie (Sonnenbergs, 2007:7)? Belasting is ' $n$ jaarlikse gebeurtenis en die waarde daarvan waarop die belastingpligtige geregtig is, moet aan die einde van elke jaar van aanslag bepaal word. Die feit dat 'n korting moontlik ná die einde van die jaar van aanslag toegestaan sal word, moet nie in ag geneem word in die bepaling van die waarde waarop die belastingpligtige vir die betrokke jaar van aanslag geregtig is nie. As die korting wel in die daaropvolgende jaar toegestaan word, sou die belastingpligtige geregtig wees op ' $n$ aftrekking vir daardie bedrag in die sin dat dit ' $n$ bedrag verteenwoordig wat nie in daardie jaar van aanslag ontvang is nie; dit verteenwoordig wel ' $n$ vermindering in die bedrag wat oorspronklik vir gelewerde goedere gehef is (Sonnenbergs, 2006:12).

Op grond van bogenoemde botsende standpunte rakende die waarde van die toevalling is dit belangrik om te besef dat die bewoording van elke ooreenkoms uniek is en ' $n$ sterk invloed sal hê op die hof se uitleg en interpretasie daarvan (Stiglingh et al., 2012:25).

\subsection{Vergelyking van die inkomstebelastinghantering vir die belasting- pligtige (verbruiker) wat vereffeningskorting ontvang teenoor die verskaffer wat vereffeningskorting toestaan}

Volgens inkomstebelastingbeginsels, indien pariteit nagestreef word, word een belastingpligtige op ' $n$ aftrekking geregtig terwyl die ander belastingpligtige bruto inkomste moet erken. Die effek op die verskaffer se belasbare inkomste is dieselfde ongeag of hy die korting toegestaan op bruto of netto basis by belasbare inkomste insluit. Indien die verskaffer met die oorspronklike verkooptransaksie die bruto bedrag by bruto inkomste insluit, sal die verskaffer met die toestaan van korting in ' $n$ daaropvolgende jaar van aanslag op ' $n$ aftrekking geregtig wees (toepassing van beginsels uit ITC 1815 [2006] 68 SATC 312). Indien die beginsels van GUD Holdings Ltd v CSARS [2007] 69 SATC 115 toegepas word, sal die verskaffer op die datum van verkoop die bedrag na aftrekking van vereffeningskorting as bruto inkomste erken. Deurdat die vereffeningskorting toegestaan die waarde van die bruto inkomste insluit en gevolglik die totale belasbare inkomste verminder, kan dit ook beskou word asof die verskaffer in ' $n$ aftrekking geslaag het.

\section{DIE IMPAK VAN DIE BRUMMERIA RENAISSANCE-UITSPRAAK}

In CSARS v Brummeria Renaissance (Pty) Ltd and others [2007] 69 SATC 205 was die belastingpligtige ' $n$ ontwikkelaar wat rentevrye lenings verkry het ten einde eenhede in ' $n$ aftree-oord te bou in ruil vir lewensregte op die eenhede wat aan die inwoners van die eenhede verskaf is. Die Hoogste Hof van Appèl het beslis dat die rentevrye lening die quid pro quo was wat die ontwikkelaar ontvang het in ruil vir die toekenning van die gebruik van die ontwikkelde eiendom, en dat die ontwikkelaar belas moet word op die waarde van die rentevrye lening (met ander woorde die addisionele waarde indien dit vergelyk word met 'n rentedraende lening).

Ná afloop van die uitspraak in CSARS v Brummeria Renaissance (Pty) Ltd and others [2007] 69 SATC 205 het kommer onder belastingpligtiges geheers oor hoe wyd die Kommissaris die beginsels wat in die saak neergelê is, sou toepas (Croome, 2008). 0p 30 Junie 2010 het die SAID Interpretasienota 58 uitgereik wat die wyse uiteensit waarop die Kommissaris die uitspraak in 
CSARS v Brummeria Renaissance (Pty) Ltd and others [2007] 69 SATC 205 sal toepas. Die doel van die interpretasienota is om ' $n$ uiteensetting te gee van die hantering van ontvangstes of toevallings in die vorm anders as in kontant vir doeleindes van die 'bruto inkomste'- definisie en die betekenis van die begrip 'bedrag' soos vervat in die 'bruto inkomste'-definisie. Interpretasienota 58 (paragraaf 6.1) bepaal dat die beginsels van die Brummeria-saak in alle gevalle toegepas kan word waar voordele in ' $n$ ander vorm as geld (soos die reg om 'n rentevrye lening te gebruik) toegestaan word in ruil vir goedere verskaf, dienste gelewer of enige ander voordeel gegee.

Die vraag ontstaan of vereffeningskorting ontvang, beskou kan word as voordele ontvang (om minder te betaal vir goedere of dienste reeds ontvang) in ruil vir ' $n$ ander voordeel wat gegee is (vinniger toegang tot kontant). Volgens Deloitte (2008) kan die bewoording in die uitspraak van CSARS v Brummeria Renaissance (Pty) Ltd and others [2007] 69 SATC 205 baie wyd geïnterpreteer word. Op grond hiervan kan voordele soos korting ontvang as bruto inkomste geag word (Deloitte, 2008).

Ten einde verdere bewys te lewer dat die beginsels van CSARS v Brummeria Renaissance (Pty) Ltd and others [2007] 69 SATC 205 wel op vereffeningskorting ontvang toegepas kan word, is Van Heerden and Others v $S$ [2010] 73 SATC 7 ondersoek. In Van Heerden and Others v $S$ [2010] 73 SATC 7 het Garth le Roux Marketing BK 'n ooreenkoms met Plattner Golf ( $\varepsilon d m s$.$) Bpk. gehad om$ wooneenhede by ' $n$ luukse gholflandgoed op kommissiebasis te verkoop. Die kommissie op die verkooptransaksies was invorderbaar met oordrag van die eiendom verkoop en gevolglik voorwaardelik. Garth le Roux wou eiendom by Plattner Golf ( $(\mathrm{dms}$.) Bpk. namens die Le Roux familietrust koop. Garth le Roux en sy familie het onvoldoende fondse gehad om die eiendom van R1 500000 te bekom. Plattner Golf (Edms.) Bpk. was kommissie van R500 000 aan Garth le Roux Marketing BK verskuldig. Garth le Roux en Plattner Golf ( $\varepsilon d m s$.$) Bpk. het ooreengekom dat$ Garth le Roux Marketing BK die kommissie verskuldig deur Plattner Golf (Edms.) Bpk. sal kwytskeld in ruil vir ' $n$ vermindering in die koopsom met die ooreenstemmende bedrag van R500 000. Die Le Roux familietrust het ' $n$ maatskappy benoem (wat deur Garth le Roux beheer word) as die koper van die eiendom teen die ooreengekome afslag. Garth le Roux Marketing BK het afstand gedoen van die kommissie voordat oordrag plaasgevind het, gevolglik voor die kommissie onvoorwaardelik geword het. Daar is bevind dat die kommissie nooit aan Garth le Roux Marketing BK toegeval het nie en gevolglik nie binne die omvang van die algemene 'bruto inkomste'-definisie belas kan word nie.

In hierdie saak was die vraag nie of die afslag wat die maatskappy op die aankoop van die eiendom ontvang het deel vorm van bruto inkomste van die maatskappy ingevolge die algemene 'bruto inkomste'-definisie nie, maar eerder of die afslag ingevolge paragraaf (c)(ii) deel van Garth le Roux Marketing BK se bruto inkomste op grond van die dienste gelewer, moet uitmaak. Deur na CSARS v Brummeria Renaissance (Pty) Ltd and others [2007] 69 SATC 205 te verwys, het die hof bevind dat die afslag ontvang ' $n$ 'bedrag', soos vervat in paragraaf (c) in die 'bruto inkomste' definisie, verteenwoordig. Daar is verder bevind dat indien paragraaf (c)(ii) van die bruto inkomste-definisie letterlik toegepas word, die bedrag ontvang geag moet word ontvang te gewees het deur die natuurlike persoon wat die eiendomsagentskapdiens gelewer het. Daar is beslis dat paragraaf (c)(ii) nie letterlik toegepas kan word nie (vergelyk Commissioner $v$ Professional Contract Administration 2002 (1) SA 179 (T)). Die maatskappy het nie geld ontvang nie, maar wel ' $n$ voordeel wat ' $n$ geldwaarde het, naamlik afslag op die aankoopprys van die eiendom. Die hof het gevolglik bevind dat die afslag ontvang ' $n$ 'bedrag' uitmaak vir doeleindes van paragraaf (c) van die 'bruto inkomste'-definisie. Die feit dat die maatskappy geen diens 
gelewer het in ruil vir die voordeel ontvang nie, het daartoe gelei dat die hof bevind het dat die afslag ontvang nie belasbaar is in die hande van die maatskappy nie.

Die beginsel vanuit Van Heerden and Others v S [2010] 73 SATC 7 wat van toepassing is op die studie rakende die moontlike belasbaarheid van vereffeningskorting ontvang deur ' $n$ natuurlike persoon is soos volg: Die beginsels van CSARS v Brummeria Renaissance (Pty) Ltd and others [2007] 69 SATC 205 kan toegepas word wanneer ' $n$ afslag ontvang word ten einde te bepaal of ' $n$ 'bedrag' vir doeleindes van die 'bruto inkomste'-definisie deur die belastingpligtige ontvang is of aan die belastingpligtige toegeval het. ('Bedrag' in paragraaf (c)(ii) van die 'bruto inkomste'-definisie sal gevolglik dieselfde betekenis hê as "bedrag" in die algemene 'bruto inkomste'-definisie.)

\section{ANDER 00RWEGINGS}

\subsection{Vergelyking met kliëntelojaliteitsprogramvoordele ontvang}

Afslag of korting toegestaan kan beskou word as voordele soortgelyk aan ' $n$ kliëntelojaliteitsprogramtransaksie (Rowley, 2005:195). Die basiese werking van kliëntelojaliteitsprogramme is soos volg: Lede van die algemene publiek kan aansoek doen om lidmaatskap te verkry deur ' $n$ aansoekvorm te voltooi waar persoonlike inligting verstrek word. Goedgekeurde lede sal 'n lidmaatskapkaart ontvang wat tydens elke aankooptransaksie getoon moet word ten einde punte of myle te akkumuleer. ' $n$ Magnetiese strook op die agterkant van die lidmaatskapkaart sal die besonderhede van die items aangekoop, tesame met die punte of myle wat daarvoor toegeken word, versamel (Maharaj, 2008:12). Die punte of myle wat op die lidmaatskapkaart geakkumuleer word, kan later vir goedere, dienste of ' $n$ afslag op goedere of dienste tydens ' $n$ volgende aankooptransaksie ingeruil word.

Ingevolge ' $n$ kliëntelojaliteitsprogramtransaksie sal die voordeel (goedere, dienste of afslag) eers toegestaan word op die plaasvind van ' $n$ gebeurtenis wat ná die lewering (oorspronklike aankooptransaksie) volg (wanneer die punte of myle ingeruil word). Gevolglik is ' $n$ kliëntelojaliteitsprogramtransaksie vergelykbaar met vereffeningskorting (korting wat voorwaardelik toegestaan word op die plaasvind van 'n gebeurtenis wat ná die lewering volg) ontvang, in elke geval waar die inkomstebelastinghantering hiervan ter sprake is.

Brink en Viviers (2012:438) het bevind dat selfs al word kliëntelojaliteitsprogramvoordele ontvang nie tans in Suid-Afrika belas nie, bied bestaande bepalings in die Wet en verwante regspraak wel ' $n$ basis vir die belasbaarheid van ' $n$ kliëntelojaliteitsprogramtransaksie in die hande van die verbruiker as ' $n$ natuurlike persoon. In hierdie studie is aangetoon dat wanneer die verbruiker punte of myle verdien, daar aan al die vereistes van die 'bruto inkomste'-definisie voldoen word (ongeag die wyse waarop die punte of myle aangewend word) en dat die waarde van die punte of myle by die verbruiker se bruto inkomste ingesluit moet word (Brink \& Viviers, 2012:454).

Die punte of myle word toegeken op grond van die aankooptransaksie. In hierdie opsig is dit nie vergelykbaar met 'n vereffeningskorting nie, maar moontlik eerder met 'n handelskorting (i.e. korting toegestaan gebaseer op volumes aangekoop). Wat kliëntelojaliteitsprogramvoordele en vereffeningskortings egter wel gemeen het, is dat in beide gevalle ontvang die belastingpligtige 'n onvoorwaardelike reg wat tans, in die praktyk, nie belas word nie. 


\subsection{Kwytskelding van skulde}

Daar kan geargumenteer word dat vereffeningskorting ontvang soortgelyk is aan gedeeltelike kwytskelding van skulde en gevolglik nie in die hande van die natuurlike persoon belasbaar is nie.

Wanneer ' $n$ belastingpligtige se skuld kwytgeskeld word, kom ' $n$ moontlike verhaling (ingevolge die ou artikel $8(4)(\mathrm{m})$ en die nuwe artikel 19$)$ voor. Een van die vereistes wat vir die verhaling gestel word, is dat die bedrag wat kwytgeskeld word voorheen as ' $n$ aftrekking van inkomste toegelaat is. In die geval van ' $n$ niehandeldrywende natuurlike persoon sal die kwytskelding van skulde nooit as ' $n$ verhaling kwalifiseer nie, aangesien die onkoste aangegaan nie voorheen as ' $n$ aftrekking toegestaan is nie.

Die verskil tussen die kwytskelding van skulde en vereffeningskorting ontvang wat tot verskillende hantering vir inkomstebelastingdoeleindes sal lei, is soos volg: In die geval van die kwytskelding van skulde gee die belastingpligtige niks in ruil vir die voordeel ontvang nie; in die geval van vereffeningskorting, daarteenoor, word skulde vroegtydig vereffen wat die verskaffer 'n voordeel gee (vinniger toegang tot kontant).

\section{GEVOLGTREKKING}

Ingevolge vereffeningskorting wat tydens die oorspronklike aankoop- of dienslewerringstransaksie beding word, sal die verbruiker eers onvoorwaardelik geregtig wees op die korting met vroegtydige vereffening. Toevalling en ontvangs van die korting geskied gevolglik eers op die datum van vereffening en benutting van die korting. Met vroegtydige vereffening sal die verbruiker ' $n$ reg tot korting ontvang. Die waarde van die vereffeningskorting (reg tot korting) sal tydens die aankoop- of diensleweringstransaksie ooreengekom word en gevolglik kan ' $n$ spesifieke randwaarde aan die voordeel gekoppel word. Daar is bevind dat die vereffeningskorting ontvang inkomste van aard is. Hierdie stelling word ondersteun deur die beoordeling van faktore soos die bedoeling van die verbruiker, die frekwensie van transaksies, die tydperk wat die bate gehou word en die feit dat vereffeningskorting ontvang geen blywende voordeel skep nie.

Gevolglik is dit duidelik dat wanneer ' $n$ niehandeldrywende natuurlike persoon binne die voorafbepaalde tyd sy skuld vereffen ingevolge waarvan hy ' $n$ vereffeningskorting ontvang, daar op daardie datum aan al die vereistes van die algemene 'bruto inkomste'-definisie van die Wet voldoen word en dat die waarde van die vereffeningskorting by die natuurlike persoon se bruto inkomste ingesluit moet word. Indien nie, sal pariteit in so ' $n$ geval ontbreek en die fiskus aan die kortste ent trek.

Met verwysing na kliëntelojaliteitsprogramvoordele, is daar bevind dat selfs al word sekere voordele ontvang nie tans in Suid-Afrika belas nie, beteken dit nie dat die bestaande bepalings in die Wet en verwante regspraak wel ' $n$ basis bied vir die belasbaarheid van genoemde voordele nie.

Daar is verder bevind dat vereffeningskorting ontvang nie op 'n skenking of op die kwytskelding van skulde dui nie, aangesien die verbruiker 'n quid pro quo lewer (die skuld word voor die ooreengekome tyd afgelos wat die verskaffer vinniger toegang tot kontant gee) vir vereffeningskorting ontvang. 
Ten einde alle moontlike aspekte van ' $n$ vereffeningskortingstransaksie vir die niehandeldrywende natuurlike persoon wat vereffeningskorting ontvang, te oorweeg, is die inkomstebelastinghantering deur die natuurlike persoon vergelyk met die inkomstebelastinghantering deur die verskaffer wat die vereffeningskorting toestaan en die volgende is bevind: Of die verskaffer ' $n$ bedrag voor of na aftrekking van vereffeningskorting met die verkooptransaksie (ingevolge waarvan vereffeningskorting ooreengekom word) by bruto inkomste insluit, is die effek dieselfde op sy belasbare inkomste. Die verskaffer sal ' $n$ aftrekking kry vir die vereffeningskorting toegestaan op die vereffeningsdatum.

Daar is gevolglik bevind dat bestaande bepalings in die Wet en verwante regspraak wel ' $n$ basis bied vir die belasbaarheid van vereffeningskorting ontvang in die hande van ' $n$ niehandeldrywende natuurlike persoon.

\section{AANBEVELINGS}

Ten einde die insluiting van vereffeningskorting deur ' $\mathrm{n}$ niehandeldrywende natuurlike persoon ontvang by bruto inkomste te reguleer en te vergemaklik, word die volgende aanbeveel:

- Alle verskaffers wat vereffeningskorting toestaan, moet by die Suid-Afrikaanse Inkomstediens (SAID) registreer.

- Vereffeningskortingverskaffers moet aan die einde van elke jaar van aanslag aan alle niehandeldrywende natuurlike persone aan wie vereffeningskorting toegetaan is belastingsertifikate uitreik wat die waarde van die vereffeningskorting benut vir die jaar bevat.

- Vereffeningskortingverskaffers moet gevolglik rekord hou van alle niehandeldrywende natuurlike persone wat kliënte is, insluitend persoonlike inligting en vereffeningskorting toegestaan en benut gedurende ' $n$ spesifieke jaar van aanslag.

- As alternatief kan ' $n$ terughoubelasting-meganisme op vereffeningskorting ingestel word.

Hierdie aanbevelings sal ' $n$ geweldige administratiewe las op die verskaffer wat vereffeningskorting toestaan, sowel as op die SAID, plaas. Indien die SAID saamstem met die bevindings in hierdie artikel en die praktyk wat tans in Suid-Afrika toegepas word verander en wel vereffeningskorting ontvang in die hande van ' $n$ niehandeldrywende natuurlike persoon in die praktyk belas, bestaan die moontlikheid dat verskaffers van vereffeningskorting hul struktuur en werking sal verander deur eerder net pryse te verlaag of bloot sal ophou om vereffeningskorting toe te staan.

Ter regverdiging van die behoefte om vereffeningskorting ontvang te belas, moet die koste en doeltreffendheid van die maatreëls wat hierbo gelys is met die huidige verlies aan inkomste wat uit die belasbaarheid van vereffeningskorting ontvang gegenereer kan word, vergelyk word. Die impak van die belasbaarheid van vereffeningskorting op die natuurlike persoon se besluit en bereidwilligheid om goedere of dienste met ' $n$ vereffeningskorting aan te koop en die moontlike beperking op handel, moet ook oorweeg word.

Die SAID moet gevolglik riglyne formuleer ten opsigte van die inkomstebelastinghantering van vereffeningskortingtransaksies in die hande van ' $n$ niehandeldrywende natuurlike persoon.

Hierdie artikel het beginsels uitgelig wat die verwarring rondom die inkomstebelastinghantering van vereffeningskortingtransaksies in die hande van ' $n$ niehandeldrywende natuurlike persoon 
moontlik kan opklaar. Hierdie inligting kan dus as ' $n$ nuttige hulpmiddel dien vir rolspelers in die Suid-Afrikaanse belastingomgewing wanneer bostaande aangeleentheid na vore tree.

\section{BRONNELYS}

Accounting Tools. (2011). What is a trade discount. [Intyds] Beskikbaar: http://www.accountingtools.com/questions-and-answers/what-is-a-trade-discount.html. [27 Januarie 2012].

Beneke, C. (2010). Discounts and the determination of value. Deloitte and Touche VAT Handbook. [Intyds] Beskikbaar:

http://www.lib.sun.ac.za.ez.sun.ac.za/nxt/gateway.dll?f=templates $\$ f n=d e f a u l t . h t m \$ v i d=m y l n b: 10$. 1048/enu. [2 Maart 2011].

Bloch v SIR [1980] 42 SATC 7, (2) SA 401 (C).

Brink, S.M. \& Viviers, H. (2012). Inkomstebelastinghantering van kliëntelojaliteitsprogramtransaksies in Suid-Afrika. Journal of Economic and Financial Sciences, 5(2), pp. 437-458.

Business Dictionary (2011). Trade discount. [Intyds] Beskikbaar:

http://www.businessdictionary.com/definition/trade-discount.html. [27 Januarie 2012].

CIR v Butcher Bros (Pty) Ltd [1945], 13 SATC 21, AD 301.

CIRv Delfos [1933], 6 SATC 92, AD 242.

CIR v People's Stores (Walvis Bay) (Pty) Ltd [1990], 52 SATC 9, (2) SA 353 (A).

CIR v Visser [1937], 8 SATC 271, TPD 77.

Clegg, D. \& Stretch, R. (2012). Income and capital. Income Tax in South Africa. [Intyds] Beskikbaar: http://www.lib.sun.ac.za.ez.sun.ac.za/nxt/

gateway.dll?f=templates $\$$ fn=default.htm $\$ v i d=m y l n b: 10.1048 /$ enu. [4 April 2012].

Commissioner v Professional Contract Administration [2002], (1) SA 179 (T).

Croome, B. (2008). SARS note clarifies Brummeria interpretation. [Intyds] Beskikbaar:

http://www.ens.co.za/newsletter/briefs/10_11_08\%2001\%2001lr1011LAW_AL_6.pdf. [4 Desember 2012].

CSARS v Brummeria Renaissance (Pty) Ltd and others [2007], 69 SATC 205, HHA 99

Deloitte (2008). The Brummeria Judgment. [Intyds] Beskikbaar:

http://www.saica.co.za/integritax/2008/1597_The_Brummeria_Judgment.htm. [27 Januarie 2012].

Geldenhuys v CIR [1947], 14 SATC 419, (3) SA 256 (C)

GUD Holdings Ltd $v$ CSARS [2007], 69 SATC 115, (N)

Huxham, K. \& Haupt, P. (2012). Aantekeninge oor Suid-Afrikaanse Inkomstebelasting. Roggebaai:

Hedron Tax Consulting and Publishing CC.

Investopedia (2011). Cash discount. [Intyds] Beskikbaar:

http://www.investopedia.com/terms/c/cash-discount.asp\#axzzleWaaD7y5. [27 Januarie 2012].

ITC 1815 [2006], 68 SATC 312.

ITC 1645 [1995], 61 SATC 31. 
ITC 1185 [1972], 35 SATC 122.

ITC 692 [1950], 16 SATC 509.

ITC 677 [1949], 16 SATC 245.

Jordaan, K., Kolitz, M.A., Stein, M.L. \& Stigligh, M. (2005). S/LKE: Suid-Afrikaanse Inkomstebelasting 2005. Durban: LexisNexis.

Lace Proprietary Mines Ltd v CIR [1938], 9 SATC 349, AD 267.

Lategan WH v CIR [1926], 2 SATC 16, CPD 203.

Maharaj, A. (2008). Awareness perceptions and effects of customer loyalty programmes within the retail sector of the Durban Metropolitan area. Ongepubliseerde Meestersverhandeling. Suid-Afrika: Universiteit van Suid-Afrika.

Mooiv SIR [1972], 34 SATC 1, (1) SA 675 (A).

Ochberg v CIR [1933], 6 SATCl, CPD 256

Republiek van Suid-Afrika. (1962). Inkomstebelastingwet nr. 58 van 1962. Pretoria: Staatsdrukkery. Republiek van Suid-Afrika. 2011. Belastingadministrasiewet $n$ r. 28 van 2011. Kaapstad: Staatsdrukkery.

Rowley, J. (2005). Customer relationship management through the Tesco Clubcard loyalty scheme. International Journal of Retail \& Distribution Management, 33(3), pp. 194-206.

SARS (2010). Interpretasienota 58. The Brummeria case and the right to use loan capital interest free.

SBI v Aveling [1978], 40 SATC 1, (1) SA 862 (A).

SIR v Silverglen Investments (Pty) Ltd [1969], 30 SATC 199, (1) SA 365 (A).

Sonnenbergs, દ.N. (2007). Accrual of settlement discounts. Integritax, 96, pp. 6-8.

Sonnenbergs, E.N. (2006). Discount allowed to customers - does this constitute gross income or not? Integritax, 88, pp. 11-12.

Stiglingh, M., Koekemoer, A.D., Van Schalkwyk, L., Wilcocks, J.S. \& De Swardt, R.D. (2012). SILKE: SuidAfrikaanse Inkomstebelasting 2012. Durban: LexisNexis.

Stretch, R. \& Silke, J. (2010). The meaning of 'settlement' and settlement discounts. Taxgram.

[Intyds] Beskikbaar:

http://www.lib.sun.ac.za.ez.sun.ac.za/nxt/gateway.dll?f=templates $\$ f n=d e f a u l t . h t m \$ v i d=m y l n b: 10$. 1048/enu. [2 Maart 2012].

Van Heerden and Others $v$ S [2010], 73 SATC 7

Welch's estate v Commissioner for SARS [2005], (4) SA 173 (HHA).

Williams, R.C. (1995). Income tax in South African cases and materials, $3^{\text {td }}$ edition. Durban: Butterworths. 